\title{
In/Visible Peoples, In/Visible Lands: Overlapping Histories in Wang Chia-hsiang's Historical Fantasy
}

DOI:

10.1163/24688800-00201002

\section{Document Version}

Accepted author manuscript

Link to publication record in Manchester Research Explorer

\section{Citation for published version (APA):}

Payne, C. (2019). In/Visible Peoples, In/Visible Lands: Overlapping Histories in Wang Chia-hsiang's Historical Fantasy. International Journal of Taiwan Studies. https://doi.org/10.1163/24688800-00201002

\section{Published in:}

International Journal of Taiwan Studies

\section{Citing this paper}

Please note that where the full-text provided on Manchester Research Explorer is the Author Accepted Manuscript or Proof version this may differ from the final Published version. If citing, it is advised that you check and use the publisher's definitive version.

\section{General rights}

Copyright and moral rights for the publications made accessible in the Research Explorer are retained by the authors and/or other copyright owners and it is a condition of accessing publications that users recognise and abide by the legal requirements associated with these rights.

\section{Takedown policy}

If you believe that this document breaches copyright please refer to the University of Manchester's Takedown Procedures [http://man.ac.uk/04Y6Bo] or contact uml.scholarlycommunications@manchester.ac.uk providing relevant details, so we can investigate your claim.

\section{OPEN ACCESS}




\title{
In/Visible Peoples, In/Visible Lands: Overlapping Histories in Wang Chia-hsiang's Historical Fantasy
}

Christopher N. Payne ${ }^{1}$

\begin{abstract}
This essay considers two narrative texts by the nature essayist and fiction writer Wang Chiahsiang (Wang Jiaxiang); namely, the short story collection titled On Lamatasinsin and Dahu Ali (1995), and the novella Mystery of the Little People (1996). Structured round ethnographic journeys into the Taiwanese mountainous hinterland, the texts concern the main protagonists, two earnest (Han) Taiwanese ethnographers, who narrate stories that traverse the island's histories, lands, and written remnants. The paper argues that the two stories purposefully overlap multiple historical, colonial and environmental encounters and temporal moments as a means to fictionalise the past as inherently heterarchical. The tales thus fabulise new literary spaces in which the Taiwanese relationship to yesteryear -- the peoples, the lands -- can be cognised alternatively.
\end{abstract}

\section{Keywords:}

Wang Chia-hsiang; Taiwanese literary and colonial history; narrative; environmental relations

\footnotetext{
${ }^{1}$ Dr Christopher N. Payne teaches Chinese and East Asian Studies at The University of Manchester. His main areas of research are on literature and visual culture from across the Sinosphere, particularly from Taiwan, Hong Kong, and Southeast Asia. Contact via email at: christopher.payne@ manchester.ac.uk.
} 
International interest in ecological theory and criticism from East Asia has been growing over the last decade. Critical works by Karen Thornber (2012) and Simon C. Estok and WonChung Kim (2013) have introduced an Anglo-American scholarly audience to ecocriticism written by East Asian academics, critics and writers. The translation of Wu Ming-yi’s (吳明 益) novel, The Man with the Compound Eyes (複眼人 fuyanren, 2013), has drawn additional attention to environmentally themed literature from this part of the world, and in this case from the island of Taiwan. Indeed, Taiwan's contribution to the field of ecocriticism was further underscored by the publication of an edited volume in 2016 titled Ecocriticism in Taiwan: Identity, Environment, and the Arts. The current paper intends to add to the discussion on environmentally-oriented literature from Ilha Formosa by focusing on two texts by the often-overlooked nature essayist and novelist Wang Chia-hsiang (王家祥 Wang Jiaxiang).

In the pages that follow, I argue that Wang's literary engagements with Taiwan's colonial and ecological histories bring previously 'invisible' peoples, places and pasts into sight if only by means of literary narration. I contend, moreover, that this making visible of what was once unseen, or at least what as neglected for much of the island's recent past, transforms the reading experience, resulting in the emergence of blended or overlapping histories -- the fictional bleeding into and disruption of the factual. Wang's tales thus destabilise conventional retellings of Taiwan's colonial and postcolonial history, in effect interrupting the experience of the past by thrusting the earnest reader into a hesitant form of existential proximity to other narrative conceptualisations of yesteryear. The two stories examined below, it will be argued, highlight the o/Other (l'autre/Auturi) of history by means of grafting fictional narratives onto factual historical moments, creating literary palimpsests of the past that not only question history writ large, but also the environmental situatedness of Taiwan's 
many different peoples. Before closely examining the two stories, however, a brief discussion of Wang Chia-hsiang's literary oeuvre is necessary to better position the author in the ecoliterary scene of Taiwan.

Born in 1966 in Kaohsiung, Wang Chia-hsiang began his literary career in the early 1980s as an essayist and short story writer primarily concerned with ecological themes. Much of his early work has generally been classified as nature writing (自然寫作 ziran xiezuo), with his first major publication being in 1980. Titled Civilisational Savagery (文明荒野 wenming huangye), all four stories in this collection have animals as their main protagonists, and all deal with the conflict between the animal world and human society (usually, it is the latter that disrupts/destroys the former). Throughout the remainder of the decade Wang continued to publish ecologically concerned pieces of writing, mostly nonfictional essays. These works ranged from emotive treatises outlining his affective and intellectual engagement with 'the wild', his conflicted response to the sometimes harsh brutality of eat or be eaten, and his overall concern for the well-being of natural habitats. Other compositions had an activist flavour and argued for greater respect for nature, with a focus on the idea that humanity should just let nature be and cease polluting it. Finally, certain essays by Wang employed a more philosophical perspective and served as meditations on the potential benefits of nature for humanity.

The ecological critic and scholar Ming-tu Yang (1998) describes these early pieces as possessing 'deep ecological ethics' that implore 'irresponsible and avaricious people to stop interfering with nature' (307). They were also Wang's 'attempt to persuade government authorities to keep the wilderness free from contamination by urbanization projects' (307). According to Yang (1998), Wang's nature writing served as his platform to show 
'government officials and citizens the value of wilderness as indispensable to the health of citizens', and yet something that should be left untouched (307). In the rapidly urbanising society of Taiwan in the late-1970s, throughout the 1980s and into the 1990s, Wang Chiahsiang's essays seemed to call for a slower pace of life, of a need to stop and smell the roses, but to refrain from cutting them.

From the early 1990s onwards, Wang shifted his attention to historical fiction, publishing a series of short stories, novellas, and novels in quick succession. These pieces all engage to varying degrees with different historical moments from Taiwan's past, both real and imagined. The first of these is a short story collection entitled On Lamatasinsin and Dahu Ali (關於拉馬達仙仙與拉荷阿雷 guanyu Lamada Xianxian yu Lahe Alei, 1995). This volume was followed by the short novel Mystery of the Little People (小矮人之謎 xiaoairen zhi mi, 1996), then Mountains and Seas (山與海 shan yu dao, 1996), Toppling Wind of the Inner Sea (倒風內海 daofeng neihai, 1997), Ghostly Sea Images-The Gill People (海中鬼影--鰓人 haizhong guiying-sairen, 1999) and, lastly, The Monsters (魔神仔 moshenzai, 2002). All have been described as historical fantasy (歷史奇幻小說 lishi qihuan xiaoshuo) and all mark a change in Wang's literary style. Commenting on this change, Wang (1992) himself has suggested that his earlier nature essays and stories had not wholly succeeded in awakening readers to the perilous plight of the environment in a quickly modernising Taiwan. This is not to say, however, that he believed his efforts in the 1980s achieved little by way of tangible results. Indeed, environmental activism in Taiwan during the decade -- of which Wang played an active role -- did help to raise awareness about the creeping ecodegradation across certain parts of the island. Nevertheless, Wang did seem to apprehend the somewhat harsh reality that nonfictional nature writing does not always attract as wide a readership as more 
popular forms of literature, and thus its ability to transform the means by which people view their place in the environment is perhaps limited (Wang, 1992: 9). In addition, in another essay a few short years later, written alongside the first volume in his historical fantasy, Wang also made note of his greater appreciation of the intimate connection between peoples, cultures, lands and histories, remarking that this filiality was already 'deep and wide' (1995: $71)$.

In a manner of speaking, then, Wang's ecological anxieties carried over into a concern for history as well. His historical fiction fused his earlier disquiet over the treatment of the natural environment with a broader and more profound anxiety not just for the neglected landscape, but also for the overlooked cultural histories, places and peoples of Taiwan. As novelist Wu Ming-yi (2004) has suggested in his analysis of Wang Chia-hsiang's historical fantasy, it is as though Wang, believing that there is/was no means by which 'the wild' could be peacefully reconciled with humanity, sought to create that harmonious world in fiction (524-525). Wang himself has stated that:

Historical fiction presents an even deeper engagement with ecological concerns and nature writing [...] it pries open the colonial histories of the island, the Qing, the Dutch, the Spanish, Koxinga, the Japanese, and highlights all of their struggles to possess Taiwan's land and resources; this is about the relationship between peoples and land; this is what I have discovered in writing historical fiction (Wang, quoted in Guo 1996: 28). ${ }^{2}$

\footnotetext{
${ }^{2}$ All translations are mine unless otherwise noted.
} 
In order to accomplish this fusion of different genres and write what Patrick Murphy (2000) has labelled 'nature-oriented literature', ${ }^{3}$ Wang delved into the island's past. He scoured through the vestiges of Taiwan's history over the last four hundred plus years and selected previously marginalised moments or epochs. Once he had chosen a historical background, he began to write, fictionalising where appropriate, tales of yesteryear. In many ways, Wang's historical fantasies have breathed (new) life into days gone by and have created an intricate tapestry that blends historical and present anxieties about society and nature together.

\footnotetext{
${ }^{3}$ In Farther Afield in the Study of Nature-oriented Literature (2000), Murphy argued that ecocriticism, especially as practised in the United States, needed to move beyond an almost exclusive focus on the nonfictional essay, a tradition inherited from Henry David Thoreau. According to Murphy, critics needed to consider how environmental themes and concerns also populated other genres. To better do this, he proposed a taxonomy whereby 'nature-oriented literature' served as the umbrella term, and nestled underneath were the nonfictional essay, what he called 'nature writing', as well as 'nature literature', which included fiction and poetry, 'environmental writing', or nonfictional essays that delved into real world concerns for our threatened environment and growing ecodegradation, and finally 'environmental literature', or fictional works that similarly highlighted and explored real world concerns for the environment but from the perspective of invented narratives. In the eighteen years since Murphy proposed this taxonomy, many others have adopted it, expanded on it and furthered the study of environmental themes in multiple textual forms (as has Murphy himself). Greg Garrard (2004; 2014), Lawrence Buell (2003; 2005), Timothy Morton (2007; 2010; 2013) are notable examples of how the discipline and its theoretical infrastructure has matured over the course of the new millennium. In the case of Taiwan, I see Wang Chia-hsiang's historical fiction fitting well under Murphy's latter subgenre of 'nature-oriented literature', and find it a useful category to examine environmental themes in Taiwanese literature as a whole. Two other examples might be Song Zelai’s 宋澤萊 Ruined Taiwan (廢墟台灣 feixu Taiwan), written in 1985, and Egoyan Zheng's 伊格言 more recent Ground Zero (零地點), written in 2013. Both novels deal with the issue of nuclear power and the environmental and cultural devastation wrought by meltdowns.
} 
Commenting on Wang Chia-hsiang's historical fantasy series, Andrea Riemenschnitter (2009) believes that it aims to construct a 'shared cultural imaginary' that integrates 'the strange encounters of Taiwan's yuanzhumin [原住民] (aboriginal peoples) with the so-called civilised peoples into a colourful saga of local historical experience' (175). His narratives reflect his desire to use 'fiction to awaken his readers' green consciousness and to mobilise against those contemporary forms of internal colonisation that threaten to exhaust the island's natural resources and cultural heritage faster and more thoroughly than ever before in Taiwan's history' (177-178). For Riemenschnitter, Wang Chia-hsiang's intention is to narrate 'visions of harmonious coexistence for our globalising patchwork societies'; his 'fiction is both readily accessible and digestible, and in this way easily transcends the boundaries of class and ethnicity’ (179-180).

Shu-ching Chen (2002) makes similar arguments concerning Wang's historical fantasy series, but also raises reservations about his engagement and use of aboriginal myths insofar as the novels potentially oversimplify tribal histories in their effort to raise the green consciousness of their readers (72). (I touch on this point below when discussing the trope of 'going native' [Colley 2000] and how it problematises, to a degree, Wang's historical fiction.) Shu-fen Tsai (2016) gives the impression of actually falling victim to Wang's (potentially inadvertent) oversimplification of aboriginal myths in that she seemingly embraces, almost without reservation, the utopian images of Taiwan's aboriginal histories as they are narratively conveyed. Finally, Yu-chen Cheng (2010), focusing closely on the metaphorical function of gui 鬼, or ghosts, in Wang's tales, argues that these 'ghosts' are illustrative -- for Wang at least -- of the intimate environmental-historical interconnections, those violent and those not, among the various peoples who have populated the island. The series thus points, according to Cheng, in the direction of harmonising Taiwan's future by underscoring the island's 
layered, one might say overlapping, pasts; even if it does not, it must be admitted, arrive there.

These analyses are instructive, but further questions come to mind: are Wang's novels necessarily promoting an ethnically and culturally diverse society? Is his historical fantasy series a form of tree-hugging, feel-good treatises of diverse peoples learning how to live together in some utopian environmental-cultural balance? Is there an underlying politics to his work, and if so, what role might such a politics play apropos the contested and politicised nature of Taiwanese history, or, more accurately, histories, both of peoples and lands? As Cheng (2010) suggests, Wang's tales are not only stories of harmonious belonging, but rather narratives that articulate a sense of precariousness as well; a precarity between the premodern and modern, between the preindustrial civilisation of Taiwan's aborigines and the industrialised world of colonial Japan, and later, by analogy, the Han Chinese (133).

There is, then, a question of blending and merging, of making visible the unseen, of appropriating and fictionalising the multiple cultural, historical and environmental interactions that suffice Taiwan's history. To my mind, Wang's historical fantasies function as tendrils searching out and exploring heterarchical linkages between compound cultural, historical and environmental belongings. By the emplotment of horizontal as opposed to vertical relationships between peoples, histories, and lands, I argue that Wang's fictional tales narrativise historical, ecological and civilisational moments of overlap, thus underscoring the complex nature of Taiwan's many pasts. To examine how his fiction operates in this manner, let us now turn our attention to the short story On Lamatasinsin and Dahu Ali, before analysing the longer work Mystery of the Little People. 


\section{Blending Histories}

Wang's first story in a collection that has tales that span the island's history from the first Dutch colonial contact up to and including the tumult of the 1945 disintegration of Imperial Japan, takes as its main protagonist the erstwhile Japanese amateur ethnographer Mori Ushinosuke 森丑之助 (1877-1926). And before probing into the story itself, it is important to relate, at least briefly, the personal history of this man as it serves as vital character background for Wang's narrative. In fact, this aspect of the narrative evidences the first instance of historical blending insofar as the actual history of the man Mori Ushinosuke inhabits the literary persona scripted in the fictional story.

During the early colonial period, Mori Ushinosuke was a fairly well-respected scholar and ethnographer, despite his lack of professional training. His contributions to the study of Taiwan's flora and fauna, as well as to the study of its aboriginal peoples (many of the tribal classifications that are still currently used today were first coined by Mori and the more wellknown and scholarly trained Torii Ryūzō ${ }^{4}$ 鳥居龍藏 [1870-1953]), served to provide muchneeded information for Japan's early efforts to implement governmental control over the island. Publishing numerous essays and observations throughout his amateur career, Mori distinguished himself as a man sympathetic to the plight of Taiwan's aboriginal population early on in his career. Throughout most of his residency on the island, he was quite vocal in the promotion of more conciliatory policies for 'managing' (理蕃 lifan) Taiwan's mountain peoples (Mori, 2012).

\footnotetext{
${ }^{4}$ For an interesting examination of Torii Ryūzō and the role he played in the construction of knowledge on Taiwan's aboriginal cultures, especially by means of photography, see Wong (2004).
} 
Regrettably, most of Mori Ushinosuke's policy suggestions were ignored, especially beginning with the Sakuma Samata (佐久間左馬太, 1844-1915) period of colonial rule (1906-1915) when a more aggressively assimilationist agenda was promoted by the government. Eventually, Mori became disheartened by the authorities' unwillingness to soften their stance toward the aborigines, so much so that he resigned from his official posts and abandoned all work with the government. As Robert Tierney (2010) argues in his study on Japanese colonial policy concerning Taiwan's 'savages', 'in his later years, Mori excoriated the colonial policies of the Japanese state' for effectively 'eliminating the very object the ethnographers wished to study, that is, the aborigines themselves' (87). Dejected and humiliated, in 1926, Mori boarded an ocean-liner headed for Japan. But it was a destination he would never reach: upon docking, all that remained of him were his shoes and belongings -- presumably he had thrown himself into the sea.

This unique individual, a small, unassuming man, educated in classical Chinese, a man who possessed an uncanny ability to learn aboriginal languages, who had trekked into the wilderness unarmed and without escort, a man who once boldly offered up his head to a 'mercilessly' anti-Japanese Bunun (布農 bunong) warrior, who had broken aboriginal taboos and stolen the severed heads belonging to a warrior village (he would later write an apologetic article denouncing his thievery), a man who by all accounts admired and endeavoured to protect Taiwan's aboriginal cultures, died rather unceremoniously, and, for all intents and purposes, ignored (Mori, 2012). Or at least, that is the official history. But, not for Wang Chia-hsiang and his pen: it is Mori’s 'death' in 1926 that gives literary inspiration for On Lamatasinsin and Dahu Ali. 
Wang's story begins in the present-day (the 1990s) with an intrepid young (Han) Taiwanese ethnographer engaged in discussion with an elderly Bunun cultural informant. The old man has shown him a worn and tattered diary once belonging to his father. It is written in Japanese, a language the old warrior comprehends when spoken, at least to a degree, but also a language for which he is illiterate. Beseeching the young ethnographer to tell him what the diary says, wondering if it will shed light on whom his father really was, the young Taiwanese academic reluctantly takes hold of the decaying pages and promises the old man to do what he can. The next section of the tale serves as a metafictional comment on the physical diary itself, giving a real-world 'substance' to the fiction and thus further complicating the separation between the actual and the invented. The ethnographer reflects upon the first few pages of the 'real' diary in which the diarist emphasises the importance of concealing his identity not from the aboriginals, but from the Japanese authorities. There is mention of the diarist's thoughts on the colonial policies of 'management', the ironic 'savageness' of the implementation of imperial dictates, and the fear the author feels in being discovered. To give fullness to the narrative, Wang Chia-hsiang follows up the second section of the short story with the translation of the diary itself. Focalising (Bal, 2007: 142160) the narrative in such fashion, the readers are thus invited to take part in the illusion of realness, thus blending fact and fiction.

The first diary entry states in no uncertain terms that his decision to 'go native' is final, there is -- there can be -- no going back, no going 'home' (Wang, 1995: 7). Cognisant of the ramifications of his decision and his new status, the diarist remarks that he can no longer describe the aboriginals as 'barbarian', as foreigners (蕃 fan), for he is now one of them (7). He then carries on telling of his early days as a member of the village, about how his ability to speak Japanese and Chinese allowed him to assist the aborigines in dealing with the 
colonial gendarmes, as well as the plains peoples, many of whom identified as Han Chinese. Evidently, his language skills helped the villagers avoid being taken advantage of by unscrupulous colonial administrators and crony capitalists, a service deemed so significant to the village-head that he gave one of his daughters to the Japanese man as his wife. Before learning more of the story, the Taiwanese ethnographer interrupts his 'translation' to say that what he is reading is 'stranger than fiction' (Wang, 1995: 11).

The 'translation' then continues and we are given our first introduction to the men who would become the 'mythic' heroes of the Bunun: Lamatasinsin and Dahu Ali. ${ }^{5}$ What follows are synopses of actual historical events that took place during the first part of the twentieth century when Japan attempted to solidify its control over Taiwan's hinterland. Numerous references are made to the ill-conceived policy of confiscating aboriginal rifles, a move that engendered fierce resistance, chiefly on the part of the Bunun tribe. Here the story establishes concrete links with historical events, namely the Tahun/Dahun Incident (大分事件 dafen shijian) in May 1915, which was centred around present-day Zhuoxi Township (卓溪鄉) in Hualien county. Opposing the confiscation policies and the generally aggressive, assimilationist machinations of the imperial authorities, the real Dahu Ali is remembered as leading a Bunun attack on the Japanese, beheading at least twelve Japanese officials

\footnotetext{
${ }^{5}$ According to Haisul Palalavi 余明德 (2005), the real Dahu Ali is said to have been born in either 1854 or 1869 and to have died in 1941 or 1943.
} 
(apparently seven by his own hand), ${ }^{6}$ and causing mayhem to the operations of the colonial machine.

Shu-yuan Yang (2003) examines this event and others connected to it, as well as the subsequent historical aftermath, contending that the written records today and the memorialisation of the event have far superseded the oral retellings of what in reality happened, blending history and memory together to create the 'hero' Dahu Ali and the stoicalness of the Bunun peoples. Haisul Palalavi further explores the mythologisation of the Tahun Incident, calling into question the central role supposedly played by Dahu Ali, at least according to how the event is remembered in the present-day. He suggests, in fact, that Dahu Ali may not have been the key figure in the uprising at all, but rather that his name has simply been taken to symbolise the supposedly ever-present anti-Japanese sentiment felt by Taiwan's aboriginal population during the colonial period. The degree to which Dahu Ali was involved in initiating the event is thus conveniently overlooked (Haisul Palalavi 2005). Whatever the case may be, it is interesting to note that both studies list Wang Chia-hsiang's On Lamatasinsin and Dahu Ali in their respective bibliographies, but neither mention the fact that the short story is most certainly fiction and not history (at least not in the official sense of the word).

To return to Wang's narrative, in the 'translation', the diarist also tells us of how he was given an aboriginal name that meant 'friend'. He meditates on the creeping influence of

\footnotetext{
${ }^{6}$ In 2015, centenary celebrations were held in and around Zhuoxi Township to commemorate the Tahun/Dahun Incident. In most celebratory events, Dahu Ali’s heroism and skill with a blade was greatly remarked upon. See, for instance, the brief article in the 11 April 2015 edition of the Taipei Times.
} 
modern conveniences into the village and its effect on the tribe's culture (their reliance on rifles instead of traditional weapons being an ironic case in point). Afterward, he states his aim clearly: he wishes to give the Bunun people, a tribe that possess no written language, a textual trace, a history written from 'their' perspective (however incongruous this may seem given the fact that he is not ethnically Bunun). The diary is pitilessly honest with respect to how it describes the Japanese, saving no measure of animosity when describing the vicious military pacification campaigns launched by the colonial forces. Later, he speaks of his joy of becoming a father (to a son, no less, which is interesting insofar as the real Mori had only a daughter as legacy). We then learn of the capitalist advances into tribal areas as they forced open new lands for camphor harvesting and production, which again mirrors actual historical developments, most especially the construction of the Daguan 大觀 pass that allowed for further Japanese penetration into the mountainous hinterland (and greater environmental destruction under the boot of modern industry).

In one particularly poignant section (pages 21-24), the diarist reflects upon the headhunting raids carried out by Taiwan's aborigines (there is an echo here of Mori's intimate knowledge of the practice alluded to above). He seems to be trying to explain it, or perhaps justify it, highlighting its 'logicalness', as it were. In no small measure, we could say that he idealises the savageness of the custom, or at least depoliticises it in a manner similar to that of how the actual Mori Ushinosuke did in his own ethnographic studies of Taiwan's aboriginals. In Mori's work -- and in Wang's short story -- there is the suggestion that headhunting, alongside its many other cultural roles, in fact reduced the amount of conflict by settling 
disputes quickly, succinctly. ${ }^{7}$ In contrast, it was modern, mechanised society and its armed warfare that caused devastation on a grand scale -- modern societies exterminated, utterly, peoples and places. A successful hunting of a head, on the other hand, demonstrated one village's strength over another, further violence was unnecessary.

The remaining diary entries relate a series of running battles waged by Lamatasinsin and Dahu Ali against their Japanese 'oppressors'. We learn of Dahu Ali’s son, Aziman Siking, and his more conciliatory position vis-à-vis the Japanese (32). The narrator then speaks of how, with Lamatasinsin in hiding and Dahu Ali holed up in a mountain refuge, Aziman moves a large contingent of the tribe down into the plains, acquiescing to Japanese demands for the Bunun -- for all of Taiwan's tribes -- to submit and become fully-fledged imperial subjects. Again, the diarist comments on the successful Japanese infiltration into the mountain wilderness by means of the construction of modern infrastructure: roads, it seems, will doom the tribes after all. Finally, Lamatasinsin and his sons are captured (39), and not long after, Dahu Ali surrenders. The diarist ends his tale on a forlorn and sorrowful note: 'the age of tribal heroes has come to an end' (40).

The remaining pages of Wang Chia-hsiang's narrative return us to the fictional present of 1990s Taiwan. The young ethnographer is unsure of what he has 'translated'. All of the signs

\footnotetext{
${ }^{7}$ According to Tierney (2010), Mori thought to remove the practice of headhunting from the discursive structures of imperial discourse, idealising it away from the tropes of premodern versus modern and barbarism versus civilisation. Instead, headhunting was to be analysed scientifically: 'Mori abstracted the practice of headhunting from the context of Japan's colonization and analyzed it solely as a cultural phenomenon. Indeed, he made it an object of scientific observation precisely by abstracting it from the messy context of imperial conquest and from institutions of colonial rule' (83).
} 
point to the fact that the diary was written by Mori Ushinosuke, a personal hero, and a man who was thought to have died in 1926 (here again we witness this fusing of the real and the fictional mentioned above). Yet, the narrator muses, he cannot be completely sure. He is thus conflicted. Publicising his discovery would, on the one hand, breathe new life into an important yet neglected figure in Taiwan's environmental and colonial history. On the other hand, it would figuratively 'return' Mori -- if indeed the diarist is Mori Ushinosuke -- to Japaneseness. In a manner of speaking, it would subsume and subvert the diarist's entire effort to be a Bunun warrior by reasserting a Japanese identity he had disavowed; an identity, moreover, that the diarist could only ironically describe as 'savage' (and this is to say nothing of the impact it would have on the now old Bunun warrior who gave the young Taiwanese man the diary to translate in the first place).

The narrative ends with the ethnographer returning to the village to speak one final time with the old warrior. He reflects upon the subjugation of Taiwan's aboriginal population, how wave after wave of outsiders have come to the island and pushed its aboriginal peoples further and further into the mountains, into a state of precariousness that it has been impossible to escape from. The old tribesman considers how the Japanese colonial authorities 'savagely' subdued the various clans, and how retrocession to Han Chinese control in 1945 extended, and in some cases made worse, the destruction of aboriginal culture and lands. Torn as to what to do, the ethnographer finally makes a decision and tells the old man that he can be sure of only one thing: his father, the diarist, was a heroic Bunun tribesman (whether or not he was Japanese, whether or not he was Mori Ushinosuke, remains narratively undetermined and deliberately so). 
Framed as an ethnographic encounter, this story and many others in the historical fantasy series structure an important distinction between the premodern world of aboriginal Taiwan and the modernity of imperial Japan (and later the modernity of the Han Chinese/Taiwanese). The demand to order the world, as Mori Ushinosuke did in real life with his cataloguing of flora and fauna, as well as his tribal designations, could not help but force the other of history -- the oral lives of the Bunun and other groups -- into modern conceptualisations of civilisational 'standards'. Mori, in this real sense, participated in the destruction of his object of study. But in the short story discussed, the Taiwanese ethnographer's reluctance to bring these peoples into the modern, regimentalised world of official history highlights a profound uncertainty about what the narrator is doing. His hesitancy in relation to the modern task of ordering nature for the sake of knowledge calls into question the very importance of this knowing.

To carry this further, I would argue that in a certain sense Wang Chia-hsiang's tale constructs parallel, overlapping worlds. The first constructed world is that of the aborigines (fictionally) living in balance with nature. In Wang's narrative, theirs is an environmental-civilisational model that does not require a mechanised, textual form of history. On the other hand, the parallel world is the modern one: a civilisation of text-based knowledge, of knowing and thus 'ordering' and controlling (or dominating) nature. This is the historical background which serves as prelude to the fictional narrative. From this interpretative point of view, Wang's short story seems to envision only a future for the former model; the modern world, in contrast, can end only in destruction. And yet, his characters, the Taiwanese and Japanese in On Lamatasinsin described above, the Han Chinese in other stories in the collection, and in the story to be discussed below, do not fully forsake the world of modernity and embrace the (fictionalised) premodern world of nature. 
I would argue here that Wang is grappling, if unintentionally, with the theme of 'going native'. From one perspective, the narrative seems to privilege a premodern bucolic past, even if this past can never be truly known. The tale mythologises Bunun history; it borrows from their oral traditions to weave together a 'heroic' account of the tribe without wholly questioning the veracity of this 'history'. Wang, it could be said, is therefore performing an act of what the Ojibwa storyteller Lenore Keeshig-Tobias (1994) refers to as cultural 'poaching', whereby the ethnic majority -- the American white majority for Keeshig-Tobias - appropriates the stories of the aboriginal minorities as a means to 'fool themselves [and] also fool the public by drawing attention away from the real issues and struggles facing native peoples' (118). This is done, Keeshig-Tobias continues, either to imagine a 'simpler, more at-one-with-nature stage of human development' or as a way to 'atone for the horrible reality of Native-white relations' (119), or in our case, Japanese/Han-Aboriginal relations. But I would contend the narrative resists this designation of 'poaching', at least to a certain extent, insofar as it remains open-ended. On Lamatasinsin is somewhere in-between the dynamic of appropriation and respect.

From one angle, Wang has indeed appropriated Bunun stories to articulate a historical tale of Taiwan for today, one that highlights a form of resistance towards outsiders and a more harmonious relationship to the land, qualities that have ostensibly been lost in a modern/industrial Taiwan (of course, there is no mention that the Han Taiwanese were once 'outsiders' themselves). There is thus a suggestion, if implicit, that Bunun history can be understood only from the outside, from the perspective of the imperial/majority voice that possesses the language and the means to write that record. But from another point of view, Wang's choice to leave the narrative open, the reluctance of his narrator to fully bring that 
knowledge of the past into the modern world, however fictional it may be, suggests a peculiar form of hesitancy, an unwillingness, as it were, to wholly appropriate the others of history.

The fictional Mori (and by corollary Wang Chia-hsiang), is guilty of cultural appropriation, of the belief that he has to tell the Bunun story and that they, as subjectivised aboriginals outside imperial modernity, cannot. However, there is a politics of otherness about Mori Ushinosuke, too (and thus about Wang). The fictional character is estranged not only from Japan, but also from the tribe and place he would call home, in the literal and emotional senses of that word. Wang's positioning in the environmental-activist debates in Taiwan in the 1980s and 1990s, his interactions with aboriginal peoples, also suggest a certain form of estrangement from the mainstream Han Taiwanese majority, especially when that majority tended to -- and still does to a degree -- privilege economic development over environmental and cultural protection. In the narrative, Wang seems to be situating Mori as the insideroutsider. He is neither Japanese, nor Bunun (nor Han); he is not the imperial oppressor, nor is he the colonised other. He is, for all intents and purposes, what I shall call the 'other-another'.

I arrive at this interstitial term first through a consideration of Emmanuel Levinas' concept of the 'face-relation' and how it articulates a sense of being-for-others, which is how I choose to read the fictional Mori's emplotment within Wang Chia-hsiang's text. For Levinas (1969; $1987 ; 1999 ; 2001)$, our existence is determined pre-ontologically by the face of the o/Other (l'autre/Auturi). It is this encounter that, according to Levinas, permits us to see ourselves as Beings, or existents, as he calls them. But, this encounter also carries with it a priori demand that we are responsible for the face of the many others we inhabit reality with -- this is 'the "imperative demand" of the face of the other' (Levinas, 2001: 115). To put it another way, the recognition of our Being is held 'hostage' to our recognition of other existents, for the 'I' 
is 'the chosen hostage, the chosen one. An ethics of the encounter - sociality. For all eternity, one man answerable for another. From unique to unique. Whether he looks at me or not, he “regards me"; I must answer for him' (italics added) (204).

In this conceptualisation of Being, Levinas takes care to draw a distinction between l'autre, on the one hand, and Auturi, on the other. These two terms delineate two forms of alterity: the former is that which is perceived consciously and can thus be subsumed by one's self, understood, as it were, through knowing, or what Levinas calls 'work'. As Edelglass, Hatley and Diehm (2012) state, for Levinas 'the other (autre) ... is a thing like other things, understood from a phenomenological perspective as having a meaning constituted by consciousness' (6). The latter term, in contrast, is that which is forever inassimilable, resistant to absorption into the same, it is that which remains absolutely Other; this is the existent we are fundamentally held hostage to, the site of our exceptional responsibility (6-8). In a manner of speaking, we could argue that for the fictional Mori, the Bunun are the other (l'autre) that can be known by means of his conscious writing of their history. But there is a problem here: they remain inalterably Other (Auturi) by their refusal to be what is expected of them, they care not for his history. But this does not go far enough, inasmuch as Mori is not the other of the Bunun. To further the theoretical framework I am attempting to construct, we need to take the second step on my way to other-anotherness. To do that, we need to consider a key dimension of Being that Levinas did not, namely, the question of Being under the domain of colonial relations and the imperial command to bring the colonised subject into material knowledge. To do this, John Drabinski's (2011) postcolonial reformulation of Levinasian philosophy is instructive. 
For Drabinski, Levinas' conceptualisation of the face-relation elides contemplation of the colonial encounter and the attendant power relations of domination and subjectivisation. $\mathrm{He}$ thus attempts to expand on Levinas' face-relation by articulating the concept of what he calls the 'other Other' in and of imperial interactions. What he means by this phrase is the 'other' of Levinas' Auturi, or the other that 'does not register as obligating', and yet for which we are still responsible (xiii). For Drabinski, the 'other Others' are 'the unfamiliar and unanticipated Others, the Others of historical experience, the alien in every sense of alien' (22). In a manner of speaking, the 'other Others' are those situated out-side the (violent) infrastructure imposed on colonised peoples and lands. Moreover, the other Others are those that resist the imposition of the language of the colonial authorities -- resist to be what the coloniser expects them to be, even if that struggle ultimately proves futile. To my mind, in On Lamatasinsin, Mori's contact with the Bunun people textualises this dynamic precisely: they are not the primitive savages of the mountains as described in earlier historical ethnographies. Instead, Wang's narrative description brings a certain vitality to the Bunun peoples, even though that very vitality is under threat by the expansion of the imperial machine. The description of Mori's entanglement with the Bunun thus shifts far beyond the standard hierarchical formulations of empire. Further complicating this dynamic interaction is the fact that the Bunun tribe cares nothing for the history being written about them by this insider-outsider. In a sense, they are choosing to remain as fragments within Taiwan's colonial past, purposefully on the margins of the margins, beyond the discursive constructs of knowledge created by means of the Japanese language, at least as emplotted in Wang Chia-hsiang's (Chinese) narrative. 
This remaining outside is central to the reading I am trying to construct, as the Bunun peoples' lack of care for the written word delineates a temporal disjuncture which is key for both Levinas and Drabinski, inasmuch as:

The space between the intending subject and its Other, between sensibility and sense, or between the obsession and the obsessed-about, is measured as a temporal distance... Diachrony names distance measured by time, locating the famous 'time of the Other' both inside subjectivity and outside its measure and grasp (Drabinski, 2011: 28).

If Levinas' Auturi is configured by means of temporal distance, then the colonised other textually emplotted in On Lamatasinsin conveys Drabinski's other Others most clearly: they exist beyond the inhibiting confines of linear, progressive time, especially as perceived by the Japanese empire. The fictional Mori can be seen to be filial to his responsibility for the Bunun peoples since he is writing 'their' history and they in turn have acknowledged him by taking him into the tribe. But they remain indelibly as other Others due to their lack of interest in the written word, at least the older generation for whom the history being written about them in the language of the coloniser is a history that can never truly represent their oral past. But how does this beget the 'another' I mentioned above? It is here that I wish to take the third step and further complicate the reading I am giving to Wang Chia-hsiang's narrative by means of bringing into the frame of discussion the natural environment and the situatedness of the human and the non-human alike. To do this, I turn to how the ecocritic Patrick Murphy (1995; 2000; 2009; 2013) employs Mikhail Bakhtin’s concepts of 'answerability' and 'anotherness' to theorise an ecological poetics, or what Murphy has most recently called an ecological praxis. 
In much of his work on ecoliterature, Murphy explores the means by which ecocriticism can obtain actual praxis and situate 'ethically grounded and morally justifiable' actions in the real world (Murphy, 2013: 11). To arrive at this juncture, he borrows from Bakhtin (1990), whose conceptualisation of 'answerability' limns the human situatedness in the physical world (1). The central question for Bakhtin is this: 'what guarantees the inner connection of the constituent elements of a person? Only the unity of answerability. I have to answer with my own life for what I have experienced and understood in art, so that everything I have experienced and understood would not remain ineffectual in my life' (italics added) (1). For this answerability to be possible, one 'must take up a position outside himself, must experience himself on a plane that is different from the one on which we actually experience our own life... He must become another in relation to himself, must look at himself through the eyes of another' (italics added) (15).

According to Bakhtin, the 'looking' at one's self through another's eyes is possible only by means of transgredience, or outsideness. It is from outside that one can recognise experiential reality as always-already in a dialogical interaction with multiple perspectives, or anothers. (As seen above, Levinas [1999] phrases this dialogical interaction as one of 'answering' as well, further theorising multiple perspectives as highlighting the presence of what he terms the third, the fourth, and the many others that populate existence and underscore how the face-relation is conceived not as a binary relationship, but as infinitely multiplexed). Murphy sees in this transgredience a connection with 'the issue of anthropocentrism versus biocentrism or ecocentrism', that by elucidating an outsideness Bakhtin's work 'encourages authors and critics to see themselves "through the eyes of a [specific] another": that of the rest of the natural world at the general level and specific ecosystems, natural processes, 
plants, or animals at the particular level' (italics added) (Murphy, 2013: 11). Murphy further argues that the 'experience of adopting the perspective of another must be considered as an act of consciousness, as an act of becoming a changed person to some degree' (12). This, I would contend, returns us to the fictional Mori Ushinosuke.

The fictional characters in On Lamatasinsin are intimately enmeshed within the natural environment and the historical conditions of colonial and postcolonial Taiwan. The factual history that precedes the narrative serves as the foundation by which the story is read, insofar as the time in which it was written, the 1990s, witnessed an explosion of scholarly and popular interest in Taiwan's imperial past. Wang's Mori Ushinosuke functions, then, as 'the another' of the actual man. Wang allows him to step out-side himself and 'look' at the colonial enterprise of bringing the aboriginals into civilised knowledge, he allows Mori to sympathise with their plight, to argue on their behalf in dealings with the colonial authorities and to insert himself into the other's existence. It is through the eyes of another that Mori witnesses the destruction being wrought on the land by the colonial machine, the opening up of new roads and the tearing down of mountains to create passes to further the exploitation of natural resources. In a certain sense, the fictional Mori engages in dialogue with his historical self, if only by means of the readerly experience we obtain when reading On Lamatasinsin. If Murphy (2009) argues that 'the Another' represents 'not the Alien and not the Stranger, but the brother, the cousin, the sister, and not just the human ones, but all the creatures with whom we share the planet' (35), then in a very real sense the fictional Mori is a form of 'another': a character that stands aside and apart from the Bunun, from the colonial Japanese, from the Han Taiwanese, but only just. There remains a certain form of filiality between Mori and his many others, as there would be with a 'brother', a 'cousin', a 'sister' and so on. If, as was suggested above, the Bunun symbolise the 'other Others' that Mori to some extent 
wished to become but failed to do so, he at the same time does not become/revert to being wholly Japanese. We could therefore say that the fictional Mori is the other to both, which returns us to the question of 'going native' and cultural appropriation.

Wang Chia-hsiang chooses to have his fictional Mori Ushinosuke hold onto his Japaneseness; he chooses to deny him the possibility of becoming fully part of the Bunun tribe. The peculiar hesitancy mentioned above, the unwillingness of the narrative to fully claim Bunun history, results in Mori remaining alien, 'in every sense' of the word, as Drabinski put it (2011: 22). Indeed, any effort to make Mori a 'true native' Bunun would seem far-fetched and trite, weakening the efficacy of the short story and potentially privileging the majority's discourse in appropriating cultural others. ${ }^{8}$ As a result, then, the character is interstitially situated between the Bunun, the Japanese, the Han Taiwanese (and Wang Chia-hsiang himself, if we allow for Mori to represent the author's own awareness and hesitancy about futilely trying to 'go native'). In a manner of speaking, the fictional character is the another that has stepped out-side and has become answerable to the Bunun; he has seen the invisible, both the peoples and the land, and the imperial destruction that is laying waste to it, but he has not been

\footnotetext{
${ }^{8}$ In a certain way, the hesitancy Wang displays allows his work to resist being lumped in with the idea that majority cultures simply absorb ethnic minority stories to fabulise tales that serve only the former's interest, say the construction of Taiwanese history as being not of the mainland because of aboriginal history of the island as told by the Han Taiwanese. Elyce Rae Helford (1997) explores this issue in her analysis of Ursula K. Le Guin's short story 'Buffalo Gals'. The analysis is insightful and illustrates clearly the problematic nature of the trope of 'going native' and how it perpetuates majority control over representations of minority others. Jane Stafford's (2005) analysis of New Zealander fiction, and the appropriation of Maori legends, operates in a similar vein. But as stated above, it is the hesitancy in Wang's text that permits the story to function beyond these claims, even if Wang himself has sometimes taken for granted the manner by which he employs said aboriginal histories.
} 
absorbed into the same. In true Bakhtinian form, the interstitiality of Mori's situatedness is dialogic and always facing differing and changing perspectives. I call this the 'other-another', that which is Other (Auturi), out-side the same, separated by a diachronic measuring of time, but still an another, still the filial companion that remains answerable to all the many others.

If we allow for the fictional Mori to operate on this level, then Wang Chia-hsiang's short story serves as a powerful fictionalisation not only of Taiwan's environmental and colonial relations, but also of how the (premodern) past and the (modern) present relate to each other - but not as alienating modes of history. Figuratively speaking, these narrative worlds overlap heterarchically and not hierarchically. One period does not come before the other, and thus is not superseded by another. Instead, they blend together in Wang's fictional world. It could be argued, therefore, that Wang's narrative does not actually divest the modern world of a future, but rather suggests that such a future can only be possible through this fictional blending of past and present. This is reason why the narrator cannot fully let go of the modern accoutrements of textuality: he is cognisant of the fact that he lives in the modern wor(l)d. To put it another way, we could say that there is no going back to some perceived environmental utopia, we cannot 'go native'; instead, we need to consider new conceptualisations of possible futures. On Lamatasinsin points, I believe, in this direction, provided that we embrace the other-anotherness of the central character. The next text to be explored, Wang's Mystery of the Little People, emplots further this notion of other-anotherness and it is to this that we now turn.

\section{'Mythologising' the Little People?}

Published a year later, Mystery of the Little People shares many of the same qualities as the former short story collection. Aimed at a broader readership and containing less historical 
specificity and more reliance on myth, the narrative sets out to explore this central question: have the Little Peoples, long a part of the oral histories of the island, completely disappeared or are they still living out their lives deep in the nearly impenetrable forests of Taiwan's mountainous eastern coast? The opening chapter, establishing the first person narratorial perspective, identifies clearly the time of the story: 1993, the beginning of Taiwan's rights movements. Paralleling the story already discussed, Wang Chia-hsiang again employs a young ethnographer as a key protagonist, and we learn immediately that he has been searching for the Little People for nigh on two years. This historical and archaeological exploration into the (mythical) remnants of the island's past serves as an important linking device for Wang, enabling him to intertextually lattice together not only the tales in $O n$ Lamatasinsin and Mystery of the Little People, but also across the historical fantasy series as a whole. This is done most explicitly in the latter work, for in its first chapter we are introduced to another key character of the novel, a Bunun cultural informant who is none other than Aziman Siking, one of the first Bunun 'warriors' to acquiesce to the demands of the Japanese authorities, and the son of the late Dahu Ali. The action begins when, stirring the young ethnographer from his sleep, Aziman excitedly shouts through a telephone receiver that he 'has found the Little People' (Wang, 1996a: 6).

The second and third chapters function to 'site' the Little People in Taiwanese history by first examining the various oral myths told of their existence. Questions are then asked about their disappearance: If they did retreat into the mountains, why? Why did they subject their tribe to such a precarious existence where even the struggle for food and shelter would be extreme? Were they afraid of something? And if so, what? Was it, perhaps, civilisation? (18). Chapter three explores the 'archaeological' traces of the Little People, networking together Taiwan's prehistory with that of southeast Asia, to the islands of Java, Sulawesi, and the Malay 
peninsula, and to the Philippine islands of Mindanao and Luzon. Interspersed with 'archaeological' drawings of thatched huts, spear tips, sea shells, and the like (all hand drawn by Wang), the hypothesis put forth in the chapter is that even though the Little People may have vanished from Taiwan, the 'extended tribe' may still inhabit the islands to the south (30). These 'archaeological traces' are later said to even predate the five thousand years of Chinese 'civilisation' on the mainland (34), setting up a prehistory of Taiwan that dramatically sets it apart from the continent. ${ }^{9}$ To further extend this history, the Little People are even said to antedate Taiwan's current aborigines, who already (and perhaps debatably) stretch their histories back some eight thousand years into the past (Blust, 1999). Acknowledgement is then paid to the 'fact' that for some (as yet) unknown reason they were

\footnotetext{
${ }^{9}$ There is an echo once again here of the criticism Helford (1997) makes against Le Guin, mentioned in the previous footnote. As above, I am reluctant to wholly subscribe this criticism to Wang, but it bears noting nonetheless. As Helford states, Le Guin's story 'Buffalo Gals' 'effectively combines elements of fantasy and myth to emerge with powerful white liberal narratives' (78), but the main character 'never exhibits true commitment to the new world she "discovers" and takes without giving in return' (80), allowing for Helford to summarise Le Guin's story as 'part of a trend in contemporary mainstream American society to embrace aspects of other cultures which offer new images and visions, but to neglect or resist commitment (or even representations of commitment) to the actual struggles of these cultures for survival within the mainstream western world' (81). To some extent, this criticism could be applied to 1990s Taiwan when interest in aboriginal histories, the so-called 'maritime-ness' of the Taiwanese, and other similar narratives, were used, and continue to be used, by the Taiwanese (Han/Hoklo) majority to argue for the island's separateness from the mainland, without really delving into substantial analysis of the injustices still being felt by the aboriginal populations. In the very recent past, the situation has undergone further changes, with the government of Tsai Ing-wen 蔡英文 officially apologising in the summer of 2016 for aboriginal mistreatment over the centuries. Nevertheless, aboriginal representation in Taiwan, like many other places where aboriginal populations have endured centuries of injustices wrought by colonising powers, for example, North and South America, the Antipodes, is still limited and forms of oppression persist.
} 
continually and forcibly shunted to the margins of mainstream history, and often excluded altogether (Wang, 1996a: 36). The chapter ends by lamenting this predicament, mourning the tragic fate of the Little People who endured a series of 'ethnic clashes' that precipitated their decline: first the conflict with the now 'current' aborigines, then by proxy the Dutch and Han Chinese, followed by the Japanese, and then the Han again. All these struggles resulted in the Little People being pushed out of the lush and fertile lands of Taiwan's plains, further and further up into the mountains, finally losing the seas, the land, the bounty of Ilha Formosa and 'failing' as a people (41).

Needless to say, these early chapters set the stage for a series of intriguing if perhaps controversial questions: just what might be the place of the Little People in Taiwan's environmental, historical and cultural palimpsest? Are these people simply figments of the imagination, a tribe solely inhabiting the myths and rituals of Taiwan's aborigines? Are they beyond the physical and material terrain of the island and its current populations? Or are they, perchance, a fundamental component of the land, part of its ecological history, and thus, inevitably, part of all its current peoples? The remainder of the novel explores these themes to varying degrees, all as the ethnographer attempts to verify Aziman Siking's claim that he has 'found them' (Wang, 1996a: 6).

But this journey of discovery is not without consequences. First, let us consider the relationship between the Little People and the aborigines as viewed through Aziman's eyes. When suggestion is made by the ethnographer that today's tribes may be the filial descendants of the Little People, Aziman is stunned and unsure what to think (54). As readers, we can certainly see parallels here: what happened to the Little People and what has been happening to Taiwan's aborigines today are eerily alike. The Bunun, Saisiyat, Atayal, 
and other groups are being correspondingly pushed by civilisation, forced to conform, to accept the normative modes of culture established in Taipei and other urban centres. For Aziman, this cannot help but be a poignant, if somewhat unsettling, reminder of his own actions and 'surrender' to the Japanese mentioned above. In the chapter immediately following this conversation, the ethnographer, speaking by shortwave radio to an assistant, considers whether or not the 'archaeological traces' found by Aziman could have been left by hunters. The response is negative: Taiwan's indigenous warriors no longer penetrate deep into the woods; they no longer have the (traditional) skills to track animals in the forests (67). The suggestion here is that 'civilisation', what the Little People perhaps feared most of all, has succeeded in 'domesticating' Taiwan's tribes (an issue that is alluded to throughout the novel).

In a later chapter, it is even suggested that the Little People had sought to warn the Bunun of the impending dangers of (Japanese/Dutch/Han) civilisation, urging them to resist, but painfully aware that they were powerless to do so. Aziman wails accordingly in reference to this plight, condemning his people, and himself: 'there are no Bunun in the mountains any longer, only the spirits... and the Little People; the Bunun - they have all come down from the mountains!' (85). Aziman, forlorn, struggling with the emotions inside him, remembering the stories his father had told him about the Little People, of somehow believing that they had spoken to him when he was young, that they had somehow charged him with the task of being their spokesperson, of representing them to the outside world, could now no longer move beyond the belief that the Little People had been permanently displaced, cursed to wander forever the margins of Taiwan's history (87). Some pages later, the ethnographer asks him whether or not he believes their expedition will succeed, whether they will 'discover' the Little People or not. Aziman replies, initially in the affirmative, before qualifying his 
statement: 'the Little People don't need to be acknowledged by outsiders to exist, they don't need to be "discovered"; in truth, they are already part of the Bunun heart. The problem is that the Bunun themselves no longer believe in spirits, they've forgotten the ways of their ancestors' (96). What we see here is a tragic mourning for a past that remains forever beyond the reach of contemporary aboriginal (and Taiwanese) society. The Little People exist for the Bunun, but they can never be fully part of Bunun 'modern' society, if for no other reason than that a modern Bunun existence is a life without spirits, without the myths that made them who they are, or rather, who they were. In sum, for Aziman's Bunun tribe, the Little People's 'visibility' is opaque, blurred, shadowed and in the background, out of focus.

For the ethnographer in Mystery of the Little People, the main issue is analogous to the predicament faced by Mori Ushinosuke (the actual man), and Wang's first earnest protagonist in On Lamatasinsin: how to rationalise the fact that by studying pre/aboriginal peoples, one cannot help but destroy them, or at minimum set in process their eventual absorption into modern civilisation. This realisation is not immediate, however. Initially, in fact, Wang's ethnographer sees himself as the Little People's 'spokesperson', their 'guardian' and 'protector' (58). He does not consider his 'project' to be threatening, but the opposite. For him, acknowledging the existence of the Little People, by bringing them into knowledge -- he even plans to put them on television and on T-shirts (!) -- he considers himself to be preserving their culture, reincorporating them back into the mainstream of Taiwan today. Two pages later, however, he is already questioning this belief, seemingly aware of the reality that it is he who is the intruder, the enemy-outsider, the bringer of pollution, spiritual and otherwise. Indeed, as a Han Taiwanese, he represents the literal invasion of Taiwan by forces from the outside. If the Little People symbolise a pre-historical, pre-Han, preliterate form of existence, then his imposition of knowledge cannot help but set in motion the erasure 
of the Little People from that very same existence. Ironically, by writing their history, he deletes it.

In a later section, the ethnographer again queries his motives, wondering if his search for the Little People, for some pristine, bucolic form of life, is naught but a very personal reaction to the oppressive ennui associated with modern, city life; that perhaps it has more to do with himself than with 'discovering' their existence (76). In this, his concerns are very much the same as Aziman's: modern, city living strips the magic from life. It alienates one from the natural world around him/her. The tragedy of modern existence is perhaps not whether the magic can be brought back, but if it ever even existed in the first place.

The final section of the novel grapples explicitly with this ennui by attempting to remythologise the story of the Little People. After relating his supposed encounter with them, Aziman passes to the ethnographer a brown, decaying notebook (intertextual echoes ring out here of the first story discussed). Written in Japanese, Aziman himself does not understand it (surprisingly, perhaps, given his personal history), but he believes it to contain information relevant to the 'project'. The final chapter thus serves to be the 'translation' of this diary, wherein we learn of (another) Japanese ethnographer who went 'missing' in the mountains in the early 1900s. No doubt a (fictional) contemporary of Mori Ushinosuke, the story told in Mystery of the Little People twins that of On Lamatasinsin precisely. By purposefully linking the two stories, relating the colonial experiences of the aborigines across these two texts, Wang succeeds in bringing 'myth' back into play: the history is fantastical, but nevertheless still rings true. 
In the diary, the Japanese ethnographer relates the tale of how he lost his way in the mountains and how he was rescued by 'little people'. He notes how they would not come too close to him, fearful of his being an outsider and as a bringer of disease (literally and figuratively, if we consider modern 'civilisation' as disease itself). They will guide him out of the mountains, he says, but they will not follow him. Once back onto the main trail, the Japanese diarist bows to his rescuers, whereupon they instruct him to refrain from telling anyone about them - they do not want others wandering into the mountains in search of them. The diary ends with the Japanese adventurer swearing to keep their secret, committing the event to his personal diary only (123-126). Wang's novel then ends with Aziman asking the Taiwanese ethnographer whether or not he "has found "it", to which the reply is 'yes, he has'. Aziman acknowledges the answer, then turns his back to the sun, seemingly disinterested in asking anything further (126). As for the question concerning the diary as 'proof' of the Little People's existence, it seems not to matter, or at least it is a question that no longer possesses the same sense of intellectual-cultural urgency. Akin to the first story discussed, this tale also remains open: does the ethnographer bring knowledge of the Little People back in/to civilisation? Or will he, like his Japanese predecessor(s), consign the knowledge to his own memory, until that, like the Little People, slips out of time?

If we read the novel for its ecological potential, then certain themes become clear, most especially the alienation experienced by modern society from nature. It has already been mentioned above how the aboriginals are no longer the hunters they once were, that the imposition of modern societal norms has separated many aboriginal tribes from their traditional lands. Aziman himself remarks upon this several times, bemoaning the fact that he does not have the same relationship with nature that his ancestors had. In other sections, tribal warriors similarly complain about the growing hostility of the land, the aggressiveness of 
certain insects in attacking hunters while in the bush, voraciously sucking their blood (70). Whether this inhospitality is due to changed environmental conditions (for instance, insects clamouring after humans because of the lack of other warm-blooded animals to feed on), or simply because the tribesmen no longer possess the skills of their forbearers, is left ambiguous. There are also repeated references throughout the novel to the loss of spirit, that the land itself, once 'home' to a multitude of spiritual entities is now shorn of them. And, finally, it is worth noting that in the diary, and elsewhere throughout the text, mention is made of the uncleanliness of those from outside the Little People tribe, that those supposedly in possession of 'civilisation' are the most foul and unnatural (104).

All of these references point to a dramatic separation between nature and civilisation. Wang's ethnographer and his 'cooked' savage ${ }^{10}$ stand as perhaps unwilling symbols of a modern civilisation uprooted from its natural setting, alienated from the land, in both physical and spiritual senses. In contrast, the Little People serve allegorically as the opposite: throughout the novel the tribe functions as a fictional emblem for an 'ideal' relationship with the natural environment. In a manner of speaking, the fictionalised Little People are a people who appreciate the anotherness of nature, instead of considering it as radically separate and most likely hostile. It could be argued, then, that Wang's fictional tale displaces the colonial and postcolonial histories it is interacting with, overlaying them with each other and thus

\footnotetext{
${ }^{10}$ The Japanese employed the traditional Chinese distinction between ostensibly more 'civilised', or sinicised, aboriginal peoples (the plains aborigines in Taiwan, or pingpuzu 平埔族), and their 'uncivilised' counterparts (the mountain dwelling tribes, or gaoshanzu 高山族) by referring to them, respectively and derogatorily, as 'eaters of cooked meat' (熟蕃 shoufan) and 'eaters of raw meat' (生蕃 shengfan), or 'cooked' and 'raw' for short. For more on this distinction in traditional China, see Fiskesjö (1999) and Dikötter (2015). For the use of these terms during the Japanese colonial period, see Liao and Wang (2006) and Tierney (2010).
} 
problematising the hierarchical constructions of historical belonging. This tale, like the one above, emplots an other-anotherness that spectralises history as heterarchical. The Little People are fabulised as a utopian ideal, of a 'premodern' civilisation that exists in harmony with the natural world, but their actual historical facticity is suspect. Unlike the Bunun past related in On Lamatasinsin, the 'history' of the Little People lacks even the oral traditions that the other aboriginal tribes in Taiwan possess, or at least the Little People exist only by way of the stories told about them by the Bunun and other tribes. In this sense, the Little People are mythical, and their stories inhabit the shadows of the life-worlds of the peoples today. As mythical, and in the case of Wang Chia-hsiang's narrative, literary constructs, they are not bound by historical determinacy but rather function as free-floating signifiers actantially operative in the deep narrative of the fabulas themselves. They are thus part of Taiwan's many pasts, effective in the background on the level of other-anotherness.

\section{Other-Another Histories}

In conclusion, if we consider Wang Chia-hsiang's historical fantasy series as an intricate articulation of overlapping histories -- the emplotment of 'other-another' Taiwanese pasts -then we can suggest that these works, seen especially in the two stories discussed above, serve as important critical engagements not only into and with the lingering traces of colonialism, but also into and with the place of peoples and lands in contemporary Taiwan. By scripting imagined histories of aboriginal interactions with the colonial authorities, and with contemporary aborigines and (Han) Taiwanese, as well as their interactions with their respective natural environments, Wang's tales suture these events to actual history and thus bring them into life as possible imaginings of yesteryear. By overlaying these multiple histories together, the real and the fictionalised, the stories emphasise the heterarchical nature of the past itself and the situatedness of the many peoples and perspectives that populate it. 
To project this into the future, Wang's historical fantasies do not envision a hoped-for 'return' to a harmonious and idyllic mode of coexistence with nature, nor do they conceive of a future that must abandon wholesale the trappings of modernity (and the perceived penchant for environmental destruction so often associated with the modern).

Rather, the narratives uproot modernising discourses of hierarchical, vertical development and hostility towards aboriginal peoples and lands, and instead give voice to a future of differentialising conceptualisations of the past conceived as being otherwise. This heterarchical understanding of history allows for diverse temporal moments -- real and unreal, but still possible -- to be simultaneously accessible via Wang's texts. By intersecting narrative histories in this manner, by accentuating the fused qualities of actual history with literary creativeness, the two tales discussed in this essay rupture the neat compartmentalisations of linear, progressive History writ large. To use Wang's words, they ' $\operatorname{pr}[y]$ open the colonial histories of the island', drawing attention to the multiple 'struggles to possess Taiwan's land and resources' (Wang, quoted in Guo, 1996: 28); they thus call out for the need to interact with Taiwan's many pasts differently. In this sense, we could say that $O n$ Lamatasinsin and Myth of the Little People serve as iterations of Wang's attempt to 'answer' for the other-another, if only in a hesitant, perhaps problematical, manner. If Wang's earlier nature essays had limited impact in raising peoples' environmental and historical awareness, if they moved only a select few to consider nature and its many pasts as more than simply an object to be subjugated (much like the aborigines were considered), then perhaps it is with Wang's historical fantasies that the narrative other-anothers have most effect. By constructing what could be termed countermemories of Taiwanese history, the two stories discussed figure alternative spaces for the island's literary and environmental tales to be told. We can thus hope that they further the work of consciousness-raising in terms of stressing the necessity to 
consider other-another means by which we can exist and interact with and in our natural environment.

\section{References}

Bakhtin, Mikhail (1990) Art and Answerability: Early Philosophical Essays, trans. Vadim Liapunov with Kenneth Brostrom, Austin: University of Texas Press.

Bal, Mieke (2017) [1985] Narratology: Introduction to the Theory of Narrative, $4^{\text {th }}$ Edition, Toronto: University of Toronto Press.

Blust, Robert (1999) 'Subgrouping, circularity and extinction: some issues in Austronesian comparative linguistics', in E. Zeitoun and PJK Li (eds), Selected Papers from the Eighth International Conference on Austronesian Linguistics, Taipei: Academia Sinica, 31-94.

Buell, Lawrence (2003) Writing for an Endangered World: Literature, Culture and Environment in the U.S. and Beyond, Cambridge, MA: Harvard University Press.

Buell, Lawrence (2005) The Future of Environmental Criticism: Environmental Crisis and Literary Imagination, Oxford: Blackwell Publishing.

Chen, Shu-ching (2002)

Cheng, Yu-chen (2010) ‘Searching, confronting, recognizing, and leaving: Wang Jia-Xiang’s modern mythology for Taai' (尋䚇、遭遇、認識、離去--王家祥為矮黑人織寫的現代神 話), Research in Taiwan Studies (臺灣學研究) 9: 123-144 (in Chinese). 
Colley, Linda (2000) 'Going native, telling tales: Captivity, collaborations and empire', Past \& Present 168 (August): 170-193.

Dikötter, Frank (2015) The Discourse of Race in Modern China, $2^{\text {nd }}$ Edition, Oxford and New York: Oxford University Press.

Drabinski, John E. (2011) Levinas and the Postcolonial: Race, Nation, Other, Edinburgh: Edinburgh University Press.

Edelglass, William; Hatley, James; and Diehm, Christian (eds) (2012) Facing Nature: Levinas and Environmental Thought, Pittsburgh: Duquesne University Press.

Estok, Simon and Kim, Won-chung (eds) (2013) East Asian Ecocriticisms: A Critical Reader, New York: Palgrave Macmillan.

Fiskesjö, Magnus (1999) 'On the "raw" and the "cooked" barbarians of imperial China', Inner Asia 1(2): 139-168.

Garrard, Greg (2004) Ecocriticism, London: Routledge.

Garrard, Greg (eds) (2014) The Oxford Handbook of Ecocriticism, Oxford: Oxford University Press. 
Guo, Yumin (1996) 'Interview with contemporary Taiwanese authors: Wang Chia-hsiang' (當代成名作家訪談錄一訪王家祥), New Taiwan Literature (台灣新文學) 6:14-19 (in Chinese).

Haisul Palalavi 余明德 (2005) A Study of Dahu Ali's Tahun Event in the Japanese Era (1915 年 Dahu Ali [拉荷阿雷] 發動布農族大分抗日事件說之探討), Taiwan Historica (台灣文 獻) 16(1): 355-394 (in Chinese?).

Helford, Elyce Rae (1997) 'Going “native”: Le Guin, Misha, and the politics of speculative literature', Foundation 71 (Autumn): 77-88.

Keeshig-Tobias, Lenore (1994) 'Poaching: Is it irresponsible to appropriate Native American stories?', Utne Reader (March/April): 118-119.

Levinas, Emmanuel (1969) Totality and Infinity: An Essay on Exteriority, trans. Alphonso Lingis, Pittsburgh: Duquesne University Press.

Levinas, Emmanuel (1987) Time and the Other, trans. Richard A. Cohen. Pittsburgh: Duquesne University Press.

Levinas, Emmanuel (1999) Otherwise than Being: Or Beyond Essence, trans. Alphonso Lingis, Pittsburgh: Duquesne University Press.

Levinas, Emmanuel (2001) Existence and Existents, trans. Alphonso Lingis, Pittsburgh: Duquesne University Press. 
Liao, Ping-hui and Wang, Der-wei (eds) (2006) Taiwan under Japanese Colonial Rule, 1895-1945: History, Culture, Memory, New York: Columbia University Press.

Mori, Ushinosuke 森丑之助 (2012) Travels with Savages: Mori Ushinosuke’s Taiwan Expedition (生蕃行腳：森丑之助的台灣探險), trans. Yang Nanjun 楊南郡, Taipei: Yuanliou (in Chinese?).

Morton, Timothy (2007) Ecology without Nature: Rethinking Environmental Aesthetics, Cambridge, MA: Harvard University Press.

Morton, Timothy (2010) The Ecological Thought, Cambridge, MA: Harvard University Press.

Morton, Timothy (2013) Hyperobjects: Philosophy and Ecology After the End of the World, Minneapolis: University of Minnesota Press.

Murphy, Patrick D. (1995) Literature, Nature, and Other: Ecofeminist Critiques, Albany: State University of New York Press.

Murphy, Patrick D. (2000) Farther Afield in the Study of Nature-oriented Literature, Charlottesville, VA: University of Virginia Press.

Murphy, Patrick D. (2009) Ecocritical Explorations in Literary and Cultural Studies: Fences, Boundaries, and Fields, Lanham, MD: Lexington Books. 
Murphy, Patrick D. (2013) Transversal Ecocritical Praxis: Theoretical Arguments, Literary Analysis, and Cultural Critique, Lanham, MD: Lexington Books.

Riemenschnitter, Andrea (2009) 'Queer transnationalism: Literary anthropologies from the contact zone', in Andrea Riemenschnitter and Deborah L. Madsen (eds), Diasporic Histories: Cultural Archives of Chinese Transnationalism, Hong Kong: Hong Kong University Press, $171-188$.

Stafford, Jane (2005) 'Going native: How the New Zealand settler became indigenous', Journal of New Zealand Literature 23(1): 162-173.

Taipei Times (2015) 'Aborigines mark the 100th anniversary of the Dafen Incident', 11 April. Available online: http://www.taipeitimes.com/News/taiwan/archives/2015/04/11/2003615683 (accessed 5 June 2018).

Thornber, Karen (2012) Ecoambiguity: Environmental Crises and East Asian Literatures, Ann Arbor: The University of Michigan Press.

Tierney, Robert (2010) Tropics of Savagery: The Culture of Japanese Empire in Comparative Frame, Berkeley: University of California Press.

Tsai, Shu-fen (2016) 'Taiwan is a whale: The emerging oneness of dark blue and human identity in Wang Chia-hsiang's historical fiction', in Chia-ju Chang and Scott Slovic (eds), 
Ecocriticism in Taiwan: Identity, Environment, and the Arts, Lanham: Lexington Books, 4154.

Wang, Chia-hsiang (1980) Civilisational Savagery (文明荒野), Taipei: Morning Star (in Chinese).

Wang, Chia-hsiang (1992) Prayer for Nature (自然禱告者), Taichung: Morning Star (in Chinese).

Wang, Chia-hsiang (1995) 'The “clear earth” in local Taiwanese nature writing’ (台灣本土 自然寫作中鮮明的「土地」) Chung-wai 中外文學 23(12): 68-71 (in Chinese).

Wang, Chia-hsiang (1995) On Lamatasinsin and Dahu Ali, and other tales (關於拉馬達仙仙 與拉荷阿雷), Taipei: Jade Mountain Publishers (in Chinese).

Wang, Chia-hsiang (1996a) Mystery of the Little People (矮人之謎), Taipei: Jade Mountain Publishers (in Chinese).

Wang, Chia-hsiang (1996b) Mountains and Seas (山與海), Taipei: Jade Mountain Publishers (in Chinese).

Wang, Chia-hsiang (1997) Toppling Wind of the Inner Sea (倒風內海), Taipei: Jade Mountain Publishers (in Chinese). 
Wang, Chia-hsiang (1999) Ghostly Sea Images: The Gill People (海中鬼影--鰓人), Taipei: Jade Mountain Publishers (in Chinese).

Wang, Chia-hsiang (2002) The Monsters (魔神仔), Taipei: Jade Mountain Publishers (in Chinese).

Wong, Ka F. (2004) 'Entanglements of ethnographic images: Torii Ryūzō's photographic record of Taiwan aborigines (1896-1900)', Japanese Studies 24(3): 283-299.

Wu, Ming-yi (2004) Using Writing to Liberate Nature: Explorations into Modern Nature Writing in Taiwan, 1980-2002 (臺灣現代自然書寫的探索 1980-2002), Taipei: Da-an (in Chinese).

Yang, Ming-tu (1998) 'Ecological consciousness in the contemporary literature in Taiwan', in Patrick D. Murphy (ed.), Literature of Nature: An International Sourcebook, Chicago and London: Fitzroy Dearborn Publishers, 304-314.

Yang, Shu-yuan (2003) 'Between history and memory: Dakuanshan event and beyond' (歷史 與記憶之間: 從大關山時間談起), National Taiwan University Journal of Literature, History and Philosophy (台大文史哲學報) 19 (November): 31-64 (in Chinese). 